\title{
Prospective cohort study on adverse drug reactions on all admissions to internal medicine: Incidence, risk factors and fatality
}

\author{
Aduragbenro Adedapo ${ }^{1}$, Waheed Adedeji ${ }^{1}$, Ifetoluwanimi Adedapo ${ }^{1}$, and Kayode Adedapo ${ }^{1}$ \\ ${ }^{1}$ University of Ibadan College of Medicine
}

May 12, 2020

\begin{abstract}
Background Adverse drug reactions (ADRs) constitute major clinical burden of public health concern. Intensive adverse drug reactions monitoring in hospitals, though advocated are rare. Aims Intensive monitoring of medical patients for ADRs to assess incidence, risk factors and fatality of ADRs leading to hospital admission or occurring in the hospital. Research design and methods Prospective cohort study on 1280 adult patients admitted to the six medical wards of a tertiary institution over a 12-month period. Patients were assessed for ADRs during and throughout admission. Causality assessment and preventability of ADRs were assessed. Results Sixty-seven (5.2\%) patients had ADRs, which was the cause of admission in 46 (3.6\%), and majority $61(91 \%)$ of the ADRs were preventable. NSAIDs, 14 (20.3\%), antidiabetics, 12 (17.4\%) and antibacterial, 11 $(15.8 \%)$ were the most suspected drugs. Gastrointestinal tract (37\%), CNS (30.2\%), and skin (24.7\%) were the most affected organ/systems, while upper GI bleeding and hypoglycaemia were the most observed ADRs. ADRs led to deaths in $7(10.4 \%)$ patients, with overall case fatality rate of $0.5 \%$. Stevens-Johnson Syndrome/Toxic Epidermal Necrolysis 3/7(42.9\%) had the highest fatality rate. Risk factors, relative risk, 95\% confidence interval for ADRs were alcohol intake, 1.7 (1.04, 2.80$)$ and duration of hospital stay, $2.0(1.16,3.26)$. Conclusions Preventable ADRs are common and important cause of hospitalization and inpatients' morbidity and mortality among medical patients in Nigeria. Upper GI bleeding and hypoglycaemia, resulting from NSAIDs and antidiabetic drugs were the most observed ADRs. Strategic planning for intensive follow up of ADRs in Nigeria is advocated.
\end{abstract}

\section{Introduction}

Medical treatment represents the most commonly used treatment modalities in the world but adverse drug reactions (ADRs) from their usage pose a great limitation. Adverse drug reactions (ADRs) are an important cause of hospital admission, morbidity and mortality in hospitalised patients [1]. Prevalence of ADR-related hospitalisations in developed and developing countries reported as $6.3 \%$ (3.3-11.0) and $5.5 \%$ (1.1-16.9), respectively, and the majority of the ADRs are preventable [2]. ADRs have been reported as a significant cause of deaths among hospitalised patients. The economic burden resulting from adverse drug reactions among hospitalised patients is enormous, requiring between billion United State Dollars ( $\$ 30$ billion) annually in the US [4].

In the Western world, the incidence of adverse reaction reactions varies between $3.5 \%$ and $19.2 \%$ [5,6], while the incidence of 5.5\% was reported in Saudi Arabia [7]. In South Africa, the incidence of ADRs was reported as $6.3 \%$ [8]. Adverse drug reactions studies in Nigeria are rare and where available are retrospective [9], or from randomized controlled clinical trials $[10,11]$. Adverse drug reaction rates vary depending on the methods of ADRs detection employed in different studies. Medical record review in conjunction with patient interview yield higher ADR admission rates compared with medical record review alone.

Adverse drug reactions reporting through pharmacovigilance have been difficult in Nigeria and most studies have reported a low rate of reporting [12-15]. Particularly, intense follow up of patients in order to assess 
any adverse reaction occurring during the hospital stay is rare. Our literature search did not reveal and to our knowledge this is the first prospective cohort studies on adverse drug reactions in in-patients spanning a period of one year in Nigeria. Aim of the study is an intensive monitoring of medical patients for ADRs to assess prevalence, incidence, risk factors, preventability and fatality of ADRs leading to hospital admission or occurring in the hospital.

\section{Methods}

Study design, duration and sampling: This was a prospective cohort study conducted over a period of oneyear duration from May 2012 to April 2013 in the Department of Internal Medicine, University College Hospital, Ibadan. The University College Hospital is an 850-bed tertiary centre located in Ibadan, Oyo State in the South Western part of Nigeria. It serves as a referral centre for patients within Nigeria and neighbouring West African countries.

The study was conducted among all consented adult patients admitted to all the medical wards of the hospital during the study period. The medical wards of the University College Hospital consist of six wards with 162 beds. Inclusion criteria included all newly admitted adult patients who gave informed consent while exclusion criteria involved patients who were on admission before the commencement of the study and refusal to give informed consent.

For the purpose of this study, ADRs were defined according to World Health Organization definition [16]. The evaluation method employed included examination of the medical and nursing records, reviewing prescription charts and patients' interview.

On each day of admission, a specific questionnaire was completed for all newly admitted medical patients. Information obtained included demographics, past medical history, drug and allergy history, the reason for admission, medications taken in the last one month including herbal and other alternative care, and whether there were adverse drug reactions at admission. Thereafter, patients were intensely evaluated daily for the presence of ADRs and were monitored until discharge. Data on the particular suspected medicine(s) and reactions were also documented on the pharmacovigilance form. All the medicines the patient has received before the onset of reactions, their respective doses, routes and frequency of administration were recorded on the forms. All available clinical details, treatments and laboratory test results presented in the medical records were noted and updated from the patients in order to assess the causal relationship between medicine and reactions. Causality relationship was determined between suspected ADR and the suspected medicine.

Adverse drug reactions were classified in accordance with the WHO definition [16]. Severity and avoidability of ADRs were assessed. Fatal ADRs were those that resulted in near-death or eventual death for the patient; severe ADRs included those that were directly life-threatening and/or prolonged hospitalisation, associated with organ or system dysfunction and permanent harm; moderate, those that required treatment intervention and patient was temporarily harmed; and mild as uncomplicated primary disease requiring increased patient monitoring but neither required treatment or drug discontinuation. A reaction was considered as avoidable if the medicine involved in the ADR and/or the route or frequency of administration, dose or dosage form was inappropriate for the patient's condition. The avoidability of the ADRs was assessed with definitions and criteria developed by Hallas et al., into definitely avoidable, possibly avoidable and unavoidable [17]. However, both definitely and possible avoidable were combined to mean "avoidable". Analysis of causality assessment was done using the causality categories described by the Uppsala Monitoring Centre [18]. Analysis for causality, severity and avoidability were independently done by two of the investigators.

The length of stay was calculated for each admission and was used to determine the total number of bed days and the mean length of stay. The ADR admission rate was determined based on the number of patients admitted at least once with an ADR during the study.

Patients were classified into (1) patients without ADRs (either at admission or during hospitalisation), (2) patients with ADRs at admission, including patients admitted because of this ADR, and patients with ADRs which were not the cause of hospitalisation and (3) patients with ADRs occurring during hospitalisation. 
ADRs were also classified as type A (dose-dependent and predictable from the known pharmacology) or type B (idiosyncratic, no clear dose-response and not predictable from the known pharmacology), in accordance with the classification of Rawlings and Thompson [19]. A plausible concise classification A, B, C chronic/continuous, D - delayed, E -end of treatment and "TREND" for Temporal relationship, Re-challenge, Exclusion, Novelty and De-challenge analysis of assessing causality or detecting ADRs was however not used here [20].

\section{Statistical analysis}

Data were entered, cleaned and analysed with IBM SPSS Statistical package version 22. Figures were drawn using Microsoft Excel version 2016. Categorical variables were summarised with frequency and proportions. The continuous variables were summarised with means (standard deviation) for those that were normally distributed and median (range) if otherwise. Relative Risk (95\% Confidence Interval) was used to assess factors associated with ADRs observed. Student's t-test was used to determine the relationship between the number of drugs used by the patients and the development of ADRs. The level of statistical significance was set at less than 0.05 .

\section{Results}

The patients that were admitted over a one-year period in all the six medical wards were followed up. A total of 1280 patients were admitted to 162-bed medical wards of the department of internal medicine and accounted for 16038 patients' days. The median (range) length of hospital stay was 9 (1-153) days. The mean age of the patients was $49.3 \pm 18.2$, and the age range was 13-100 years. The male to female ratio was 1.4:1. Eight hundred and eighty-eight patients $(70.1 \%)$ had at least a secondary level of education. Patients aged 60 years and above constituted about one-third, 418(32.7\%) of all the patients admitted during the study period (Table 1).

There were 69 ADRs observed among 67 (5.2\%) patients of those admitted of whom 46 (3.6\%) had ADRs during hospitalisation. Majority of the observed ADRs, 61 (91\%) were preventable (Table 2). Gastrointestinal tract (GIT), 37\% was the most affected presenting as upper gastrointestinal bleeding (Figure 1). Twelve patients (17.9\%) had fatal ADRs and 7(10.4\%) deaths among the patients were related to the ADRs (Figure 2).

Implicated drugs for ADRs included non-steroidal anti-inflammatory drugs (NSAIDs), 14 (20.3\%) and hypoglycaemic agents, $12(17.4 \%)$ resulting in upper gastrointestinal bleeding and hypoglycaemia respectively. Other serious ADRs reported included Steven-Johnson's syndrome 7.5 \% (5/67) and Toxic Epidermal Necrolysis $1.5 \%(1 / 67)$ Table 3.

The median(range) number of drugs used by the patients within a month before admission, and while on admission were $3(0-16)$ and $6(0-28)$ respectively. There was no statistically significant relationship between the number of drugs taken a month before admission and development of ADRs [ $\mathrm{t}=0.3(1.1,0.8), \mathrm{p}=0.79]$. Similarly, the relationship between the number of drugs used while on admission and the development of ADRs was not statistically significant $[\mathrm{t}=0.8(1.4,0.6), \mathrm{p}=0.40)$. However, number of drugs on discharge was significantly less in patients with ADRs.

Of the 67 patients that developed ADRs, $7(10.4 \%)$ died, representing the overall ADRs case fatality rate of $0.47 \%$. Majority of the patients $5 / 7(71.4 \%)$ were admitted because of the ADRs, and $2(28.6 \%)$ had background HIV infection. Stevens-Johnson Syndrome/Toxic Epidermal Necrolysis 3 (42.9\%) were the most reported ADRs, and skin was the most affected organ/system, 4 (57.1\%) that resulted in deaths of the patients. Antimicrobial agents $3(42.9 \%)$ represented the most implicated drug class. The median(range) length of hospital stay among the patients was 8 (42) days (Table 4).

Alcohol intake [ RR $(95 \% \mathrm{CI})=1.7(1.04,2.80]$ and duration of hospital stay [ RR $(95 \% \mathrm{CI})=2.0(1.16$, 3.26 ] were statistically significantly related to the development of ADRs (Table 5).

\section{Discussion}


The incidence of ADRs reported in this longitudinal study is high and the majority were the causes of admission in Internal Medicine wards. This finding is similar to that of Pirmohamed et al in the UK in which prevalence of $6.5 \%$ of ADRs was reported, and more than two-thirds of ADRs led to hospital admission [21] but contracts, findings of Bouvy et al. 10.1\%, in a systematic review in Europe [22]. The differences in our findings possibly reflect different settings. There are no similar prospective studies from Nigeria with which to compare our findings. A retrospective study in Lagos reported ADRs incidence slightly higher than that of this study. However, the finding was similar to those reported from other developing countries [2]. Most of the ADRs are avoidable and preventable. This is similar to most studies in developed and developing countries $[2,22,23]$. ADRs at admission represents almost two-thirds of the reported ADRs, and mostly due to self-medication, drug abuse and /or misuse. This emphasized a need for the inclusion of community education/actions on any planned intervention to reduce the incidence of ADRs.

The system/organ mostly affected were GIT and CNS. Studies have reported the commonest system affected as CNS, GIT, and metabolic [20,24-27]. System/organ affected and the drugs implicated usually reflect the pattern of diseases in the hospital and the drugs used. Our findings are not unconnected with the drugs most abused by the populace. In Nigeria analgesics especially NSAIDs, in addition to antimicrobial agents are the most abused/misused drugs [28]. NSAIDs use have been associated with upper GI bleeding possibly on background peptic ulcer disease in Nigeria [29]. Oral Hypoglycaemic agents (OHAs)-induced hypoglycaemia resulted from self-medication, drug misuse and transcription error for prescribed OHAs and insulin. OHAs-induced hypoglycaemia as reported in this study was common as the cause of hospital admission. The consequence is grave and may worsen among alcoholics and those with background liver diseases, as well as elderly with impaired cognitive function which was the case in one of the patients. Our study is similar to studies by Mouton et al. in South Africa [30]. Contrarily, in a study in South Africa, Mehta et al reported the most common drugs for the observed ADRs to be ARTs and drugs for the management of opportunistic infections [8]. This is because of the high prevalence of HIV in the setting and the majority of the reported ADRs were among HIV/AIDs patients. Similarly, spontaneous ADRs reporting to the National Pharmacovigilance Centre in Nigeria reported antiretroviral drugs as the commonest suspected drugs and general disorders as the most common system/organ affected [31].

Most of the life-threatening ADRs reported were SJS/TEN. These ADRs are rare but fatal and responsible for the majority of the deaths recorded in this study. The drugs implicated were cotrimoxazole and herbal concoction ingested through self-medication. Cotrimoxazole in Nigeria and most LMICs are obtained as an over-the-counter drug, and this easy accessibility and affordability increase the predisposition to this lifethreatening ADRs. Studies have reported SJS/TEN as common fatal ADRs reported in developing countries [32,33]. Some drugs reported as having high risks of causing SJS/TEN are anti-infective sulfonamide, antiepileptic drugs, nevirapine and herbal medications [33], similar to our findings. Although while the genetic predisposition is still evolving, there has been an association between SJS/TEN and the use of drugs like phenytoin, carbamazepine and cotrimoxazole [34]. However, similar to our findings, a multicenter study in sub-Saharan Africa involving four countries reported cotrimoxazole as the most implicated suspected drug for the development of SJS/TEN [35]. In this study, although mostly obtained by self-medication and as a cause of admission, one of our patients on nevirapine-based ART taking cotrimoxazole as prophylaxis had SJS, while another patient on prescribed carbamazepine as branded, Tegretol and concomitantly took generic had SJS/TEN which she survived. There is, therefore, a need for sensitization of the public and possible individualization of therapy (pharmacogenomics) for those who might benefit from its usage for treatment or prophylaxis. For examples, studies have shown that individuals with HLA-B*15:02, HLA-C*06:02, and HLA-C*08:01 have several folds increase risk of developing co-trimoxazole-induced SJS/TEN [36], and HLA$\mathrm{C}^{*}$ 04:01 was associated with nevirapine-induced SJS/TEN [37].

Furthermore, the use of herbal concoction and supplements and ADRs were important findings in this study. This corroborates the need for ADRs reporting following the use of herbal medications and supplements. Although in Nigeria, NAFDAC has taken a bold step at including the spontaneous reporting of herbal medications in her national pharmacovigilance, there is a need to increase the awareness among people to report any observed ADRs to not only herbal medications registered by NAFDAC to prevent this menace. 
In addition, healthcare professionals must include a history of herbal medication intake and/or ADRs during clinical clerkship. Studies have shown that herbal medications and supplements constitute an important cause of ADRs [38-40].

Alcohol intake and duration of hospital stay are the factors that significantly associated with the development of ADRs in this study. Reasons include the fact that alcohol affect the metabolism of many drugs; alcoholdrug interactions; chronic alcohol intake and enzyme induction; chronic alcohol intake and liver diseases [41]. Alcohol has been reported as an important predictor of ADRs, especially among the elderly $[42,43]$. During hospitalisation, patients with prolonged hospital stay have the tendency of taking more medications and similar to alcohol, possibilities of drug interactions and ADRs. Development of ADRs by patients may result in prolongation of hospital stay and is a measure of severity of ADRs, however, other reasons such as the disease condition, age, multiple medications, multiple organ failure may be the reason for the prolonged hospital stay. Similar to our findings, studies have reported prolongation of hospital stay as an independent risk factor for the development of ADRs $[26,27,44]$.

\section{Conclusions}

Preventable ADRs are a common and important cause of hospitalisation and in-patient's morbidity and mortality in Nigeria. NSAIDs and OHA were the most commonly implicated drugs resulting in upper GI bleeding and hypoglycaemia respectively. The most common life-threatening ADRs that resulted in the highest number of deaths were caused by antimicrobial agents and herbal medications. Enlightenments campaign against irrational drugs use among the people, and strategic planning for intense follow up of ADRs in Nigeria are advocated.

Acknowledgment

The abstract from the study was presented at International Society for Pharmacoepidemiology (ISPE) Conference of Pharmacoepidemiology and Therapeutic Rick (ICPE) in Philadelphia, USA, in August 2019.

Author Contributions

ADAA conceived the research, was actively involved with data collection, analysis, interpretation, and drafting of the research paper. WAA participated in the development of the research, data collection, data analysis, interpretation and preparation of the first draft of the research paper. IAA and KSA participated in development of the manuscript. All authors read and approved the final manuscript.

Ethical approval

Approval for this study was given by the University of Ibadan/University College Hospital (UI/UCH) Institution Review Board (IRB) and Ethics Review committee. Written informed consent was obtained from study participants.

Conflict of Interest

The authors declare no conflict of interest

Funding

The authors received no funding for this work.

Data availability

The data is available with the corresponding author on request

\section{REFERENCES}

1. Camargo AL, Ferreira MBC, Heineck I. Adverse drug reactions: a cohort study in internal medicine units at a university hospital. Eur J Clin Pharmacol. 2006;62(2):143-9. 
2. Angamo MT, Chalmers L, Curtain CM, Bereznicki LRE. Adverse-Drug-Reaction-Related Hospitalisations in Developed and Developing Countries: A Review of Prevalence and Contributing Factors. Drug Saf. $2016 ; 39(9): 847-57$.

3. Formica D, Sultana J, Cutroneo PM, Lucchesi S, Angelica R, Crisafulli S, et al. The economic burden of preventable adverse drug reactions: a systematic review of observational studies. Expert Opin Drug Saf. 2018;17(7):681-95.

4. White TJ, Arakelian A, Rho JP. Counting the costs of drug-related adverse events. Pharmacoeconomics. 1999;15(5):445-58.

5. Davies E, Green C, Mottram D, Pirmohamed M. Adverse drug reactions in hospital in-patients: a pilot study. J Clin Pharm Ther. 2006;31(4):335-41.

6. Kongkaew C, Noyce PR, Ashcroft DM. Hospital admissions associated with adverse drug reactions: a systematic review of prospective observational studies. Ann Pharmacother.2008;42(7):1017-25.

7. Khan LM, Al-Harthi SE, Saadah OI, Al-Amoudi AB, Sulaiman MI, Ibrahim IM. Impact of pharmacovigilance on adverse drug reactions reporting in hospitalized internal medicine patients at Saudi Arabian teaching hospital. Saudi Med J. 2012;33(8):863-8.

8. Mehta U, Durhein D, Blockman M, Kredo T, Grunden R, Barnes K. Adverse drug reactions in adult medical in patients in a South African hospital serving a community with a high HIV/AIDs prevalence: prospective observational study. Br J Clin Pharmacol 2008;65:396-406. Br J Clin Pharmacol 2008;65:11.

9. Salami T, Asalu A, Samuel S. Prevalence of cutaneous drug eruptions in adult Nigerians with HIV/AIDS. Niger Postgrad Med J. 2010;17(2):160.

10. Adedapo A, Ademowo O, Adedapo K, Demissie K, Osinubi O. Potential toxicity of Chlorpheniramine plus chloroquine for the treatment of childhood malaria. Niger J Clin Pract. 2009;12(3).

11. Ashaye A, Adedapo A, Olusanya B, Adeoti C. Conjunctival hyperaemia and other ocular adverse effects on healthy African subjects after single dosing with 0.004\% Travoprost. Afr J Med Med Sci. 2007;36(1):3742 .

12. Oshikoya KA, Awobusuyi JO. Perceptions of doctors to adverse drug reaction reporting in a teaching hospital in Lagos, Nigeria. BMC Clin Pharmacol. 2009;9:14.

13. Bello SO, Umar MT. Knowledge and attitudes of physicians relating to reporting of adverse drug reactions in Sokoto, north-western Nigeria. Ann Afr Med. 2011;10(1):13-8.

14. Okezie EO, Olufunmilayo F. Adverse drug reactions reporting by physicians in Ibadan, Nigeria. Pharmacoepidemiol Drug Saf. 2008;17(5):517-22.

15. Ohaju-Obodo JO, Iribhogbe OI. Extent of pharmacovigilance among resident doctors in Edo and Lagos states of Nigeria. Pharmacoepidemiol Drug Saf. 2010;19(2):191-5.

16. Organization WH. Safety of Medicines: A guide to detecting and reporting adverse drug reactions. Geneva: World Health Organization; 2002 2002. WHO/EDM/QSM/2002.2.

17. Hallas J, Harvald B, Gram LF, Grodum E, Brosen K, Haghfelt T, et al. Drug related hospital admissions: the role of definitions and intensity of data collection, and the possibility of prevention. J Intern Med. 1990;228(2):83-90.

18. Organization WH. The Uppsala Monitoring Centre. Safety monitoring of medicinal products. Guidelines for setting up and running a Pharmacovigilance Centre. 2000.

19. Rawlins M, Thompson J. Pathogenesis of adverse drug reactions. Textbook of Adverse Drug Reactions. 1977:10-31. 
20. Maxwell S. Therapeutics and good prescribing, Adverse outcomes of drug therapy. In: Davidson's Principles and Practice of Medicine. $22^{\text {nd }}$ Edition. Editors Walker BR, Colledge NR, Ralston SH, Penman ID. Churchill Livingstone Elsevier Edinburgh 2014 pg18-39.

21. Pirmohamed M, James S, Meakin S, Green C, Scott AK, Walley TJ, et al. Adverse drug reactions as cause of admission to hospital: prospective analysis of 18820 patients. BMJ.2004;329(7456):15-9.

22. Bouvy JC, De Bruin ML, Koopmanschap MA. Epidemiology of adverse drug reactions in Europe: a review of recent observational studies. Drug Saf. 2015;38(5):437-53.

23. Alvarez PA, Bril F, Castro V, Meiville I, Gonzalez CD, Centurion IG, et al. Adverse drug reactions as a reason for admission to an internal medicine ward in Argentina. Int J Risk Saf Med. 2013;25(3):185-92.

24. Giardina C, Cutroneo PM, Mocciaro E, Russo GT, Mandraffino G, Basile G, et al. Adverse Drug Reactions in Hospitalized Patients: Results of the FORWARD (Facilitation of Reporting in Hospital Ward) Study. Front Pharmacol. 2018;9:350.

25. Lagnaoui R, Moore N, Fach J, Longy-Boursier M, Begaud B. Adverse drug reactions in a department of systemic diseases-oriented internal medicine: prevalence, incidence, direct costs and avoidability. Eur J Clin Pharmacol. 2000;56(2):181-6.

26. Camargo AL, Cardoso Ferreira MB, Heineck I. Adverse drug reactions: a cohort study in internal medicine units at a university hospital. Eur J Clin Pharmacol. 2006;62(2):143-9.

27. Tumwikirize WA, Ogwal-Okeng JW, Vernby A, Anokbonggo WW, Gustafsson LL, Lundborg SC. Adverse drug reactions in patients admitted on internal medicine wards in a district and regional hospital in Uganda. Afr Health Sci. 2011;11(1):72-8.

28. Awofisayo O, Awofisayo O, Iferi I, Akpan O. The pattern of sale and use of non-steroidal antiinflammatory drugs in rural and urban centres in Nigeria. Trop J Pharmaceut Res. 2008;7(3):1013-8.

29. Rukewe A, Otegbayo JA, Fatiregun A. Clinical characteristics and outcome of patients with upper gastrointestinal bleeding at the emergency department of a tertiary hospital in Nigeria. Ann Ib Postgrad Med. 2015;13(2):89-93.

30. Mouton JP, Njuguna C, Kramer N, Stewart A, Mehta U, Blockman M, et al. Adverse drug reactions causing admission to medical wards: A cross-sectional survey at 4 hospitals in South Africa. Medicine (Baltimore). 2016;95(19).

31. Awodele O, Aliu R, Ali I, Oni Y, Adeyeye CM. Patterns of adverse drug reaction signals in NAFDAC pharmacovigilance activities from January to June 2015: safety of drug use in Nigeria. Pharmacol Res Perspect. 2018;6(5):e00427-e00427.

32. Saka B, Gnassingbe W, Akakpo S, Mahamadou G, Teclessou J, Mouhari-Toure A, et al. Reasons for inpatient admissions to the dermatology department in Lome, Togo : Trends between 1992 to 2005 and 2005 to 2016. Med Sante Trop. 2018;28(3):270-2.

33. Lerch M, Mainetti C, Terziroli Beretta-Piccoli B, Harr T. Current Perspectives on Stevens-Johnson Syndrome and Toxic Epidermal Necrolysis. Clin Rev Allergy Immunol. 2018;54(1):147-6.

34. Rodriguez-Martin S, Martin-Merino E, Lerma V, Rodriguez-Miguel A, Gonazalez O, Gonazalez-Herrada $\mathrm{C}$, et al. Incidence of Stevens-Johnson syndrome/toxic epidermal necrolysis among new users of different individual drugs in a European population: a case-population study. Eur J Clin Pharmacol. 2019;75(2):23746.

35. Saka B, Barro-Traore F, Atadokpede FA, Kobangue L, Niamba PA, Adegbidi H, et al. Stevens-Johnson syndrome and toxic epidermal necrolysis in sub-Saharan Africa: a multicentric study in four countries. Int J Dermatol. 2013;52(5):575-9. 
36. Kongpan T, Mahasirimongkol S, Konyoung P, Kanjanawart S, Chumworathayi P, Wichukchinda N, et al. Candidate HLA genes for prediction of co-trimoxazole-induced severe cutaneous reactions. Pharmacogenet Genomics. 2015;25(8):402-11.

37. Carr DF, Bourgeois S, Chaponda M, Takeshita LY, Morris AP, Castro EM, et al. Genome-wide association study of nevirapine hypersensitivity in a sub-Saharan African HIV-infected population. J Antimicrob Chemother. 2017;72(4):1152-62.

38. Kiguba R, Ononge S, Karamagi C, Bird SM. Herbal medicine use and linked suspected adverse drug reactions in a prospective cohort of Ugandan inpatients. BMC Complement Altern Med. 2016;16:145.

39. Kiguba R, Karamagi C, Bird SM. Incidence, risk factors and risk prediction of hospital-acquired suspected adverse drug reactions: a prospective cohort of Ugandan inpatients. BMJ Open. 2017;7(1):e010568-e010568.

40. van Hunsel F, van de Koppel S, Skalli S, Kuemmerle A, Teng L, Wang JB, et al. Analysis of Hepatobiliary Disorder Reports Associated With the Use of Herbal Medicines in the Global Suspected ADR Database Vigibase. Front Pharmacol. 2019;10:1326.

41. Alomar MJ. Factors affecting the development of adverse drug reactions (Review article). Saudi Pharm J. 2014;22(2):83-94.

42. Zopf Y, Rabe C, Neubert A, Hahn EG, Dormann H. Risk factors associated with adverse drug reactions following hospital admission: a prospective analysis of 907 patients in two German university hospitals. Drug Saf. 2008;31(9):789-98.

43. Sneha SG, Simhadri K, Subeesh VK, Sneha SV. Predictors of adverse drug reactions in geriatric patients: An exploratory study among cancer patients. South Asian J Cancer. 2019;8(2):130-3.

44. Chan SL, Ang X, Sani LL, Ng HY, Winther MD, Liu JJ, et al. Prevalence and characteristics of adverse drug reactions at admission to hospital: a prospective observational study. Br J Clin Pharmacol. 2016;82(6):1636-46.

Table 1: Sociodemographic characteristics of the patients admitted into the medical wards

\begin{tabular}{ll}
\hline Variables & Frequency (\%) \\
\hline Sex Male Female & $745(58.2) 535(41.8)$ \\
Age group(years) 20 or younger 21-29 30-39 40-49 50-59 60 or older & $80(6.2) 119(9.3) 216(16.9) 225(17.6) 222(17.3)$ \\
Education level Nil Primary Secondary Tertiary & $92(7.2) 300(23.4) 387(30.2) 501(39.1)$ \\
Alcohol intake Yes No & $286(22.3) 994(77.7)$ \\
Cigarette smoking Yes No & $122(9.5) 1158(90.5)$ \\
\hline
\end{tabular}

Table 2: Characteristics of the observed ADRs among patients admitted into the medical wards

\section{Variables}

Observed ADRs(n=1280) ADRs present before or during admission ADRs developed before admission ADRs developed dur Types of ADRs $(n=67)$ Type A Type B

Causality assessment $(\mathrm{n}=67)$ Definite Probable Possible

ADRs Avoidability $(\mathrm{n}=67)$ Avoidable Not avoidable

How suspected drugs were obtained $(\mathrm{n}=67)$ Prescribed Self-medication

ADRs Adverse drug reactions

Table 3: Drugs implicated in the observed ADRs among 1280 patients admitted into medical wards 


\begin{tabular}{|c|c|c|c|}
\hline Drug Classes & $\begin{array}{l}\text { Number of ADRs } \\
\text { Frequency }(\%)\end{array}$ & $\begin{array}{l}\text { Implicated drugs } \\
\text { (number of linked ADRs }\end{array}$ & ADRs \\
\hline NSAIDs & $14(20.3)$ & $\begin{array}{l}\text { Diclofenac (8), } \\
\text { ibuprofen (5), felvin (1) }\end{array}$ & $\begin{array}{l}\text { Dyspepsia (4), Upper } \\
\text { GI bleeding (13), } \\
\text { syncopal attack (1) }\end{array}$ \\
\hline Hypoglycaemic agents & $12(17.4)$ & $\begin{array}{l}\text { Glibenclamide (7), } \\
\text { metformin (3), insulin } \\
(2)\end{array}$ & $\begin{array}{l}\text { Hypoglycaemia (12), } \\
\text { seizure (1) }\end{array}$ \\
\hline Antibacterial & $11(15.8)$ & $\begin{array}{l}\text { Cotrimoxazole }(8), \\
\text { metronidazole }(2), \\
\text { ciprofloxacin }(1)\end{array}$ & $\begin{array}{l}\text { Toxic Epidermal } \\
\text { Necrolysis (1) } \\
\text { Stevens-Johnson } \\
\text { Syndrome (3), drug } \\
\text { eruption (3), anaphylaxis } \\
\text { (1), Peppery sensation at } \\
\text { the infusion site (1), } \\
\text { nausea and vomiting (1) } \\
\text { Severe vomiting (1) }\end{array}$ \\
\hline Antihypertensives & $5(7.2)$ & $\begin{array}{l}\text { Hydralazine (3), } \\
\text { amlodipine (1), lisinopril } \\
(1) \text {, ramipril (1) }\end{array}$ & $\begin{array}{l}\text { Stroke }(1) \text {, severe } \\
\text { hypotension }(2) \\
\text { Anaphylaxis }(1) \text { Skin } \\
\text { rashes }(2)\end{array}$ \\
\hline Antituberculosis & $3(4.4)$ & Pyrazinamide (3) & $\begin{array}{l}\text { Jaundice, Toxic } \\
\text { hepatitis }(2) \text {, recurrent } \\
\text { hypoglycaemia (1) }\end{array}$ \\
\hline Antineoplastic & $3(4.4)$ & $\begin{array}{l}\text { Vincristine (2), } \\
\text { cyclophosphamide (1) }\end{array}$ & $\begin{array}{l}\text { Severe vomiting (1) } \\
\text { Loss of consciousness } \\
(2)\end{array}$ \\
\hline Herbal remedies & $3(4.4)$ & Herbal concoction (3) & $\begin{array}{l}\text { Upper GI bleeding (1), } \\
\text { Stevens-Johnson } \\
\text { Syndrome (1), Toxic } \\
\text { hepatitis (1) }\end{array}$ \\
\hline Anticoagulants & $2(2.9)$ & Heparin (2) & $\begin{array}{l}\text { Petechial haemorrhage } \\
\text { and ecchymosis }(1) \text {, } \\
\text { bleeding from femoral } \\
\text { catheter site (1), Body } \\
\text { rash (1) }\end{array}$ \\
\hline Anticonvulsants & $2(2.9)$ & $\begin{array}{l}\text { Carbamazepine (1), } \\
\text { phenytoin (1) }\end{array}$ & $\begin{array}{l}\text { Stevens-Johnson } \\
\text { Syndrome (1) Toxic } \\
\text { Epidermal Necrolysis (1) }\end{array}$ \\
\hline Antiretroviral & $2(2.9)$ & $\operatorname{HAART}^{*}(2)$ & $\begin{array}{l}\text { Bullous skin eruption (1), } \\
\text { anaphylaxis (1) Toxic } \\
\text { Epidermal Necrolysis }\end{array}$ \\
\hline Paracetamol & $2(2.9)$ & $\begin{array}{l}\text { Paracetamol }(1), \\
\text { paracetamol + caffeine } \\
(1)\end{array}$ & $\begin{array}{l}\text { Upper GI bleeding (1), } \\
\text { skin rash, blistering of } \\
\text { the skin and mucous } \\
\text { membrane (1) }\end{array}$ \\
\hline $\begin{array}{l}\text { Supplements and } \\
\text { Vitamins }\end{array}$ & $3(4.4)$ & Vitamin C (2), GNLD (1) & $\begin{array}{l}\text { Dyspepsia (1), } \\
\text { generalized tingling } \\
\text { sensation and restlessness } \\
\text { (1), hepatic failure, acute } \\
\text { kidney injury (1) }\end{array}$ \\
\hline
\end{tabular}




\begin{tabular}{|c|c|c|c|}
\hline Drug Classes & $\begin{array}{l}\text { Number of ADRs } \\
\text { Frequency }(\%)\end{array}$ & $\begin{array}{l}\text { Implicated drugs } \\
\text { (number of linked ADRs }\end{array}$ & ADRs \\
\hline Others & $5(7.2)$ & $\begin{array}{l}\text { ATS (1), Calcium } \\
\text { gluconate (1), omeprazole } \\
\text { (1), polyethylene glycol } \\
\text { (1), normal saline } \\
\text { (Bioflex) (1) Red wine }\end{array}$ & $\begin{array}{l}\text { Anaphylaxis (1) } \\
\text { Generalised body } \\
\text { weakness and vomiting } \\
\text { Drowsiness (1) Loss of } \\
\text { consciousness (1) } \\
\text { Hyperthermia (1) } \\
\text { Hypertensive crisis (1) }\end{array}$ \\
\hline Unknown & $2(2.9)$ & & Anaphylaxis (2) \\
\hline
\end{tabular}

ADRs Adverse drug reactions, ATS-Antitetanus serum, GNLD- Golden Neo-Life Diamite International, HAART - Highly active antiretroviral therapy, NSAIDs- Nonsteroidal anti-inflammatory drugs,

Table 4: Description of the ADRs that resulted in deaths among the patients $(n=7)$ admitted into medical wards

\begin{tabular}{llll}
\hline Observed ADRs & Period of development of ADRs & Drugs implicated & Sys \\
\hline Stevens-Johnson syndrome & Cause of Admission & Cotrimoxazole & Skin \\
Stevens-Johnson syndrome (background HIV infection) & During admission & Cotrimoxazole & Ski \\
Toxic Epidermal Necrolysis & Cause of Admission & Phenytoin & Ski \\
Haemorrhage (petechiae and Ecchymosis) & During admission & Heparin & Ski \\
Upper Gastrointestinal Bleeding & Cause of Admission & Diclofenac & GIT \\
Hepatotoxicity & Cause of Admission & GNLD & Live \\
Hepatotoxicity (background HIV infection) & Cause of Admission & Pyrazinamide & Live \\
\hline
\end{tabular}

GNLD- Golden Neo-Life Diamite International, HIV Human immunodeficiency virus

Table 5: Factors associated with the development of ADRs by the patients admitted into medical wards

\begin{tabular}{|c|c|c|c|c|}
\hline Variables & Total number & $\begin{array}{l}\text { ADRs observed } \\
\text { before or during } \\
\text { admission, n (\%) } \\
\text { Yes No }\end{array}$ & $\begin{array}{l}\text { Relative Risk } \\
\text { (95\% Confidence } \\
\text { Interval) }\end{array}$ & P-value \\
\hline $\begin{array}{l}\text { Sex, } n=1280 \text { Female } \\
\text { Male }\end{array}$ & 535745 & $\begin{array}{l}31(5.8) 504(94.2) 36 \\
(4.8) 709(95.2)\end{array}$ & $1.19(0.75,1.91)$ & 0.26 \\
\hline $\begin{array}{l}\text { Age (years), } \mathrm{n}=1280 \\
\text { [?] } 64 \text { [?] } 65\end{array}$ & 974306 & $\begin{array}{l}49(5.0) 925(95) \\
18(5.9) 288(94.1)\end{array}$ & $0.86(0.51,1.45)$ & 0.33 \\
\hline $\begin{array}{l}\text { Educational Level, } \\
\text { n=1280 No } \\
\text { Secondary School } \\
\text { Education } \\
\text { Secondary School } \\
\text { Education }\end{array}$ & 392888 & $\begin{array}{l}16(4.1) 376(95.9) \\
51(5.7) 837(94.3)\end{array}$ & $0.71(0.41,1.23)$ & 0.14 \\
\hline $\begin{array}{l}\text { Average Monthly } \\
\text { Income, } \mathrm{n}=1280< \\
\# 10,000[?] \\
\# 10,000\end{array}$ & 1981082 & $\begin{array}{l}11(5.6) 187(94.4) 56 \\
(5.2) 1026(94.8)\end{array}$ & $1.07(0.57,2.01)$ & 0.47 \\
\hline $\begin{array}{l}\text { Polypharmacy, } \\
\text { n=1167 No Yes }\end{array}$ & 348819 & $\begin{array}{l}16(4.6) 332(95.4) 47 \\
(5.7) 772(94.3)\end{array}$ & $0.80(0.46,1.39)$ & 0.26 \\
\hline
\end{tabular}




\begin{tabular}{|c|c|c|c|c|}
\hline Variables & Total number & $\begin{array}{l}\text { ADRs observed } \\
\text { before or during } \\
\text { admission, n (\%) } \\
\text { Yes No }\end{array}$ & $\begin{array}{l}\text { Relative Risk } \\
\text { (95\% Confidence } \\
\text { Interval) }\end{array}$ & $P$-value \\
\hline $\begin{array}{l}\text { Alcohol intake, } \\
\mathrm{n}=1280 \text { Yes No }\end{array}$ & 286994 & $\begin{array}{l}22(7.7) 264(92.3) \\
45(4.5) 949(95.5)\end{array}$ & $1.70(1.04,2.78)$ & $0.03^{*}$ \\
\hline $\begin{array}{l}\text { Cigarette smoking, } \\
n=1280 \text { No Yes }\end{array}$ & 1221155 & $\begin{array}{l}8(6.6) 114(93.4) \\
59(5.1) 1099(94.9)\end{array}$ & $1.29(0.63,2.63)$ & 0.30 \\
\hline $\begin{array}{l}\text { Fixed-Dose } \\
\text { Combination, } \\
n=1279 \text { No Yes }\end{array}$ & 843436 & $\begin{array}{l}46(5.5) 797(94.5) \\
21(4.8) 415(95.2)\end{array}$ & $1.13(0.69,1.87)$ & 0.37 \\
\hline $\begin{array}{l}\text { Duration of hospital } \\
\text { stay, } \mathrm{n}=752[?] 9 \\
\text { days [?] } 10 \text { days }\end{array}$ & 409343 & $\begin{array}{l}26(6.4) 383(93.6) 40 \\
(11.7) 303(88.3)\end{array}$ & $2.0(1.16,3.26)$ & $0.01 *$ \\
\hline $\begin{array}{l}\text { Number of drugs } \\
\text { used a month before } \\
\text { admission }(\mathrm{n}=253) \\
\text { [?] } 3 \text { [?] } 4\end{array}$ & 113122 & $\begin{array}{ll}18(15.9) & 113(84.1) \\
21(17.2) & 101(82.8)\end{array}$ & $0.80(0.45,1.43)$ & 0.28 \\
\hline
\end{tabular}

*statistically significant

Figure legends

Figure 1: System/organ affected by the observed ADRs among patients admitted into medical wards

Figure 2: Outcome of the ADRs developed by the patients admitted into medical wards

\section{Hosted file}

BJCP Cohort ADR study Figures.docx available at https://authorea.com/users/320966/articles/ 450350-prospective-cohort-study-on-adverse-drug-reactions-on-all-admissions-to-internalmedicine-incidence-risk-factors-and-fatality 